Original article

\title{
Prevalence, incidence and molecular characterization of tape worms in Al Taif governorate, KSA and the effectiveness of Spirulina platensis as a biological control in vitro
}

\author{
Bedor O. Al-Otaibi, Nabila S. Degheidy, Jamila S. Al-Malki* \\ Department of Biology, Collage of Science, Taif University, P.O. Box 11099, Taif 21944, Kingdom of Saudi Arabia
}

\section{A R T I C L E I N F O}

\section{Article history:}

Received 9 January 2021

Revised 24 June 2021

Accepted 27 June 2021

Available online 1 July 2021

\section{Keywords:}

Moniezea expansa

Moniezea benedene

Avitellina centripunctata

Thysaniezia giardia

Stilesia hepatic

Prevalence

Incidence

Molecular characterization

Biological Control

Spirulina platensis

\begin{abstract}
A B S T R A C T
Cestoda is a class of parasitic worms in the flatworm phylum (Platyhelminthes). Most of the species-and the best-known-are those in the subclass Eucestoda; they are ribbon-like worms as adults, known as tapeworms. The results reported that about $9.94 \%$ of selected sheep were infected with tape worms in native breed. Concerning the seasonal incidence of tape worms among sheep, the results revealed that the highest percentage was recorded during winter season (11.3\%), while the lowest percentage was recorded during the spring (7.72\%). The species of tape worms recorded were Moniezea expansa, Moniezea benedene, Avitellina centripunctata, Thysaniezia giardia and Stilesia hepatic. Molecular characterization of Al Taif Moniezia species cox1 gene records four different species Me Taif1, Me Taif2, Me Taif3 and Me Taif4, that have identity ranged from 90 to $99 \%$ to species in Senegal and Ethiopia (Me13, Me14 and Me22). In vitro treatment of Monizia spp. with different concentrations (10, 20, 30 and 50 $\mu \mathrm{g} / \mathrm{ml}$ ) of Spirulina platensis extract (Blue-green Algae) affects the morphological architecture of tape worms by using scanning electron microscopy (SEM). The results revealed that Spirulina platensis extract treatment, especially for higher doses 30 and $50 \mu \mathrm{glml}$, caused the sucker opening to narrow as a result of scolex swelling more than usual, deformation of the proglottids occurred with circular areas of declare swelling along their margins and microtriches covering the whole tegument appears in several directions. In conclusion, as per of our knowledge it is the first time to record new species of Moniezia species in Al Taif governorate and the anthelmintic potential of Spirulina platensis.

() 2021 The Author(s). Published by Elsevier B.V. on behalf of King Saud University. This is an open access article under the CC BY-NC-ND license (http://creativecommons.org/licenses/by-nc-nd/4.0/).
\end{abstract}

\section{Introduction}

Sheep plays an important role in the rural socio-economic conditions as well as in the national economy in the country. In rural hilly areas, comprehensive development cannot be achieved by neglecting to develop agricultural commodities such as goats, cattle and sheep. Parasites play an important role in reducing the production of sheep and goats around the world (Lone et al., 2012).

Helminths are considered one of the most dangerous internal parasites destroying vertebrate animals, including humans.

\footnotetext{
* Corresponding author.

E-mail address: J.ali@tu.edu.sa (J.S. Al-Malki).

Peer review under responsibility of King Saud University.
}

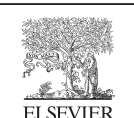

\section{Production and hosting by Elsevier}

Moreover, it reduces livestock productions as well as increases mortality rate. Sheep are considered as a valuable animal providing people with meat, milk and wool (El-Dakhly et al., 2012). Sheep have received great attention as they are one of the most important livestock and the most preferred for human consumption in the Arab countries, especially the Gulf countries (Shalaby and Amer, 2012).

In countries famous for raising sheep, tape worms are considered one of the most aggressive parasites that cause outbreaks and constitute a major problem in their raising (Al-Qureishy, 2008). It causes intestinal obstruction, perforation, perineal abscess, hepatic abscess, cholecystitis, and appendicitis. Tape worms cause poor body condition, leading to body weight loss, difficulty in lambing and kidding and low birth weight. Animals become more susceptible to other health problems due to infection with these parasites that can lead to death (Mehmood et al., 2013).

The tape worms of the genus Moniezia Blanchard, 1891 (Cyclophyllidea, Anoplocephalidae) are predominantly parasites that infect cattle, goats, sheep, antelopes and deer. They belong to the 
ruminant artiodactylus although there are a few species also known from Swedes, equids, and rodents. There are currently 15 species of Moniezia (Haukisalmia et al., 2018). Sheep and goats are the main host Moniezia expansa, but it can be found in cattle while cattle are the main host Moniezia benedeni and also it can be found in sheep and goats. Chronically, monieziosis is characterized by progressive weakness, anemic condition, reduce milk and meat production. This form is most common where mortality is low, but morbidity may reach high leads to weakness of animals and emaciation. However, heavy parasitic load may cause death (Prakash et al., 2010). Whereas Avitellina centripunctata is more common among sheep and goats than in cattle. Thysaniezia giardia is one of the tapeworms that live in the small intestine of ruminants, mainly in cattle and sheep, and oribatid mites is the intermediate host. Stilesia hepatic is called liver tapeworms because it lives in the bile ducts of sheep, goats, cattle and antelopes. It is also common in North and South America, Asia and South Africa, as well as in tropical regions.

There are three major classes of commonly used anthelmintic drugs, the benzimidazoles, imidothiazoles and macrocyclic lactones, however there is a great resistance to all those three drug classes of sheep and goats throughout the world (Waller, 2006). Therefore, there is a great demand to have a new alternative to or supplements for biological control of parasitic cestode in grazing livestock.

Microalgae play a major role in future food supplies as they can be used directly as food or as a food ingredient (Lafarga, 2019) or indirectly as animal feed (Dineshbabu et al., 2019) or as sources of bio-fertilizers and bio-stimulants (Renuka et al., et al., 2018). Microalgae have been used in other high-value applications including wastewater treatment and biodiesel production as well as in the cosmetic and pharmaceutical industries (Spolaore et al., 2006). Two of the main types of cyanobacteria are called Arthrospira platensis and Arthrospira maxima. The International Association of Applied Microbiology in 1967 recognized Arthrospira species as a future food source (Costa et al., 2019). Microalgae are very high in protein, which amounts to $60 \%$ of the dry weight (da Rosa et al., 2015). Arthrospira species are also used to develop biostimulants and bio-fertilizers due to their high protein content. Recent studies of the microalgae Spirulina platensis have shown the presence of a blue protein called phycocyanin, which belongs to the photosynthetic system, and has antioxidant and free radical scavenging properties in both in vitro and in vivo models (Morsi et al., 2016).

The current study was aimed to report the spread, incidence and molecular characterization of cestodes among sheep at Al Taif governorate in Kingdom of Saudi Arabia (KSA) and their biological control in vitro by using Spirulina platensis.

\section{Materials and methods}

A total (965) of small intestine were collected from postmortem sheep of slaughter house of Al Taif abattoir during the period from October 2018 to September 2019. Routine examination of small intestine was carried out to check for the presence of cestodes. To remove any debris from collected adult worms, washed 2-3 times with a $0.9 \%$ saline solution according to Soulsby (1986) and Mellau et al. (2010). Adult worms of recovered Moniezia from the small intestine of slaughtered sheep at Al Taif abattoir were used for later techniques.

\subsection{Molecular characterization of Moniezia spp.}

The whole DNA was extracted from a homogenized tape worm body according to Sambrook et al. (1989). Then extracted DNA was subjected to PCR using forward primer (5-
TTTTTTGGGCATCCTGAGGTTTAT-3) and reverse primer (5TAAAGAAAGAACATAATGAAAATG-3) (Shalaby and Amer, 2012) that targets cytochrome $c$ oxidase subunit $1(\operatorname{cox} 1)$ gene of mitochondrial DNA (mtDNA) with conditions: $94^{\circ} \mathrm{C}$ for 5 min followed by 30 cycles of $94^{\circ} \mathrm{C}$ for $1 \mathrm{~min}, 58^{\circ} \mathrm{C}$ for $1 \mathrm{~min}$ and $72^{\circ} \mathrm{C}$ for $1 \mathrm{~min}$, and then final strand elongation at $72{ }^{\circ} \mathrm{C}$ was done for an additional 7 min.

The PCR product of cox1 gene ( $364 \mathrm{bp}$ ) was sequenced and then data were aligned with the same fragment of cox 1 gene for other related helminths parasites (Shalaby and Amer, 2012).

\subsection{In vitro determination of the anthelmintic efficacy of Spirulina platensis (Blue-green algae) on adult Moniezia}

In a laminar flow cabinet, under sterile conditions, tape worms were washed in several changes of warm $\left(37.8^{\circ} \mathrm{C}\right)$, sterile complete RPMI 1640 culture medium containing antibiotics (streptomycin, $50 \mu \mathrm{g} / \mathrm{ml}$, penicillin, $50 \mu \mathrm{g} / \mathrm{ml}$ ). To fresh culture medium containing $50 \%$ (volume/volume), $2 \%$ (volume/volume) red blood cells of rabbits and heat denatured rabbit serum, the tape worms were then transferred as according to Ibarra and Jenkins (1984), The whole worms were incubated for $24 \mathrm{~h}$ at $37.8^{\circ} \mathrm{C}$ in an atmosphere of $5 \% \mathrm{CO}_{2}$ with algae extracts from (S. platensis) in four different concentrations $10,20,30$ and $50 \mu \mathrm{g} / \mathrm{ml}$.

\subsection{Scanning electron microscope}

After incubation, the whole tape worms were placed for $12 \mathrm{~h}$ in a 3:1 mixture of $4 \%(w / v)$ of glutaraldehyde in $0.12 \mathrm{M}$-Millonig's buffer solution $\mathrm{pH} 7.4$ and aqueous osmium tetroxide to fixed the anterior end and segments were intact. Samples were then processed for SEM according to the method previously reported by Echeverria et al. (2002).

\section{Results}

3.1. The prevalence and incidence of tape worms among sheep in al Taif governorate

From the total 965 small intestine of sheep that were collected from slaughtered house at Al Taif abattoir, only 96 (9.94\%) infested intestine was found. It was reported that the highest percent of positively was recorded in October (20\%), while the lowest percent was in September (5\%). According to seasons, it was found that the incidence of tapeworms among sheep was high in winter (11.3), while it is least in spring season (7.72) as shown in Table 1.

Table 2 shows that Avitellina centripunctata and Moniezea spp. were the most detected tape worms in infested intestine with percentage $39.5 \%$ and $36.4 \%$ from total, respectively. Moreover, it was found that the highest incidence of sheep with Moniezea spp. in Autumn with percentage 31.57\%, while with Avitellina centripunctata highest incidence in summer (12\%).

Table 1

The relationship between total incidence of tape worms and seasonal changes among sheep in Al Taif governorate.

\begin{tabular}{llll}
\hline Season & $\begin{array}{l}\text { Number of total examined } \\
\text { animals }\end{array}$ & $\begin{array}{l}\text { Number of infested } \\
\text { animals }\end{array}$ & $\begin{array}{l}\text { \% of } \\
\text { infestation }\end{array}$ \\
\hline Spring & 220 & 17 & 7.72 \\
Summer & 300 & 30 & 10 \\
Autumn & 180 & 19 & 10.5 \\
Winter & 265 & 30 & 11.3 \\
Total & $\mathbf{9 6 5}$ & $\mathbf{9 6}$ & $\mathbf{9 . 9 4 \%}$
\end{tabular}


Table 2

The relationship between total incidence of difference tape worm species and seasonal changes among sheep in Al Taif governorate.

\begin{tabular}{|c|c|c|c|c|}
\hline Season & Avitellina centripunctata & Moniezea spp. & Thysaniezia giardia & Stilesia hepatic \\
\hline Spring & $7.8 \%$ & $5.8 \%$ & $6.2 \%$ & $3.2 \%$ \\
\hline Summer & $12 \%$ & $10 \%$ & $8 \%$ & $0 \%$ \\
\hline Autumn & $9.04 \%$ & $31.57 \%$ & $0 \%$ & $0.95 \%$ \\
\hline Winter & $11.78 \%$ & $3.95 \%$ & $7.3 \%$ & $8.48 \%$ \\
\hline Total & $39.5 \%$ & $36.4 \%$ & $15.6 \%$ & $8.3 \%$ \\
\hline
\end{tabular}

\subsection{Molecular characterization of Moniezia spp.}

Four-different species of Moniezia spp. were initially determined by the BLAST program on NCBI (http://www.ncbi.nim.nih.gov/) based on the (cox1) sequences of type strains. All isolates were identified with type strain of Moniezia spp. and it was labelled them as Me Taif1, Me Taif2, Me Taif3 and Me Taif4, respectively. Those four different strains were all obtained from sheep in Al Taif governorate and their sequence were compared with different
Moniezia species in Senegal and Ethiopia. In which Me13, Me14 were found in Ethiopia and Me22 was found in Senegal, that were already found in Genbank with accession numbers AB821384.1, AB821385.1 and AB821393.1, respectively (Yanagida and Nakao, 2013a,b,c). Table 3 represents the identity and coverage percentage of the four-different isolated strains and the percentages of identity with other Moniezia expansa strains. The percentage of identity were ranged from 90 to $99 \%$; in which Al Taif strains Me Taif1, Me Taif3 and Me Taif4 have identity percentage 99\% in alignment to

Table 3

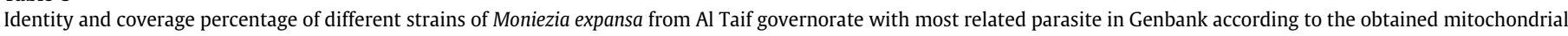
cytochrome $c$ oxidase subunit 1 ( $\operatorname{cox} 1)$ sequence.

\begin{tabular}{|c|c|c|c|c|}
\hline \multicolumn{2}{|c|}{ Most related parasite in Genbank } & \multirow[t]{2}{*}{ Query covering \% } & \multirow[t]{2}{*}{ Identities (\%) } & \multirow{2}{*}{$\begin{array}{l}\text { Site of change } \\
\text { found in Al Taif strains }\end{array}$} \\
\hline Suggested names & Name of gene and Accession No. & & & \\
\hline Me Taif1 & $\begin{array}{l}\text { Moniezia expansa mitochondrial cox1 gene for cytochrome } c \\
\text { oxidase subunit 1, partial cds, haplotype: Me13. AB821384.1 } \\
\text { (Yanagida and Nakao, 2013a). }\end{array}$ & 100 & 99 & $\begin{array}{l}\text { Me13 at } \\
\text { bp-- } \\
970 \mathrm{C} \\
\text { Me Taif1 at the } \\
\text { same site } \\
-\rightarrow \mathrm{T}\end{array}$ \\
\hline Me Taif2 & $\begin{array}{l}\text { Moniezia expansa mitochondrial cox1 gene for cytochrome } c \\
\text { oxidase subunit 1, partial cds, haplotype: Me22. AB821393.1 } \\
\text { (Yanagida and Nakao, 2013c). }\end{array}$ & 100 & 90 & $\begin{array}{l}\text { Several sites as } \\
\text { shown in Fig. } 1\end{array}$ \\
\hline Me Taif3 & $\begin{array}{l}\text { Moniezia expansa mitochondrial cox1 gene for cytochrome } c \\
\text { oxidase subunit 1, partial cds, haplotype: Me13. AB821384.1 } \\
\text { (Yanagida and Nakao, 2013a). }\end{array}$ & 100 & 99 & $\begin{array}{l}\text { Me13 at bp } \\
\overrightarrow{-\rightarrow} 936 \mathrm{~T} \\
\text { Me Taif3 at the } \\
\text { same site } \rightarrow \mathrm{C}\end{array}$ \\
\hline Me Taif4 & $\begin{array}{l}\text { Moniezia expansa mitochondrial cox1 gene for cytochrome } c \\
\text { oxidase subunit 1, partial cds, haplotype: Me14. AB821385.1 } \\
\text { (Yanagida and Nakao, 2013b). }\end{array}$ & 100 & 99 & $\begin{array}{l}\text { Me14 at bp } \rightarrow 1089 \mathrm{G} \\
\text { Me Taif } 4 \text { at the } \\
\text { same site } \rightarrow \text { A }\end{array}$ \\
\hline
\end{tabular}

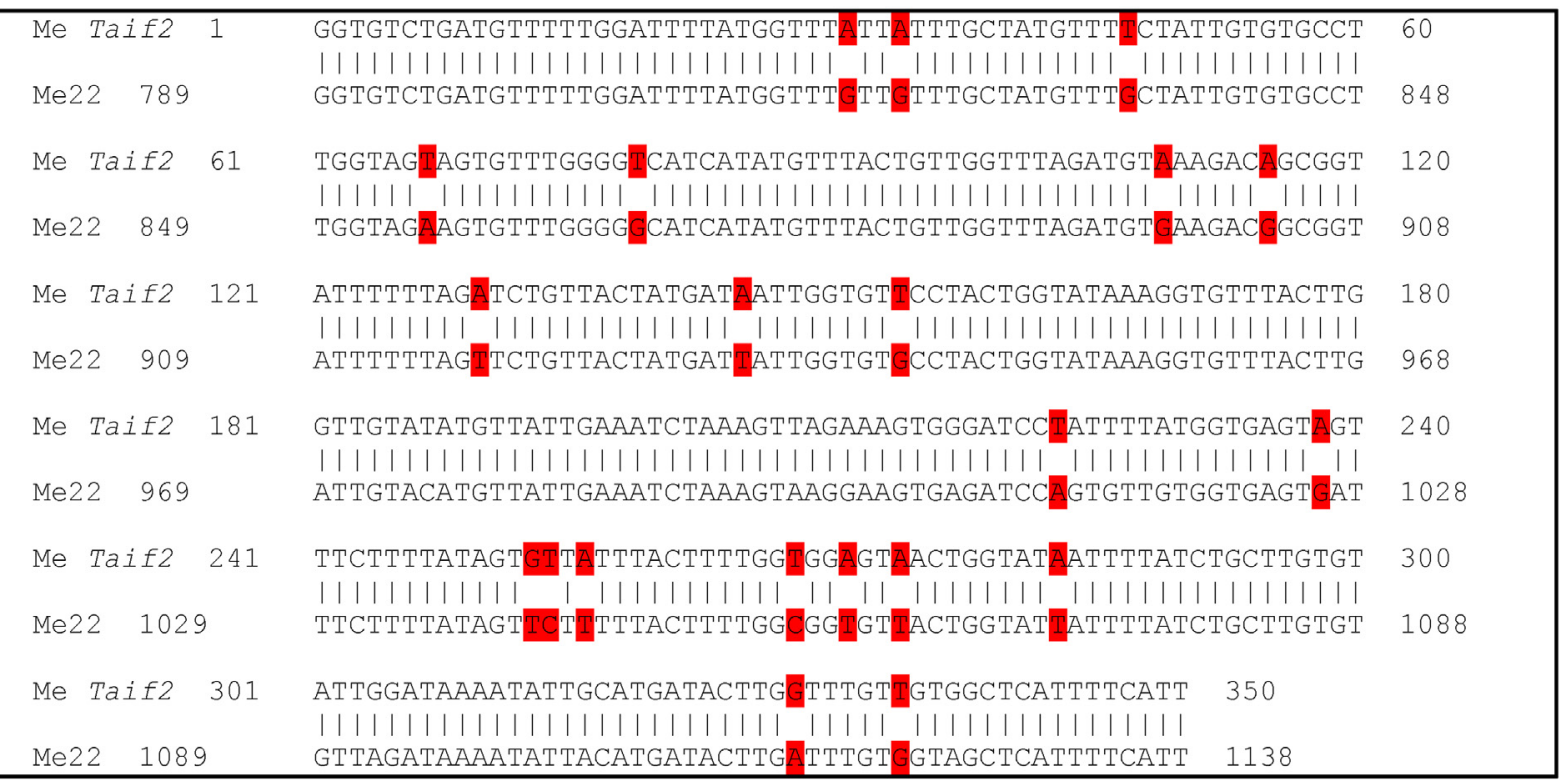

Fig. 1. Alignment of the partial sequences of cytochrome $c$ oxidase subunit 1 (cox1) gene between Me Taif2 and Me22 showing $90 \%$ identity using BLAST. 

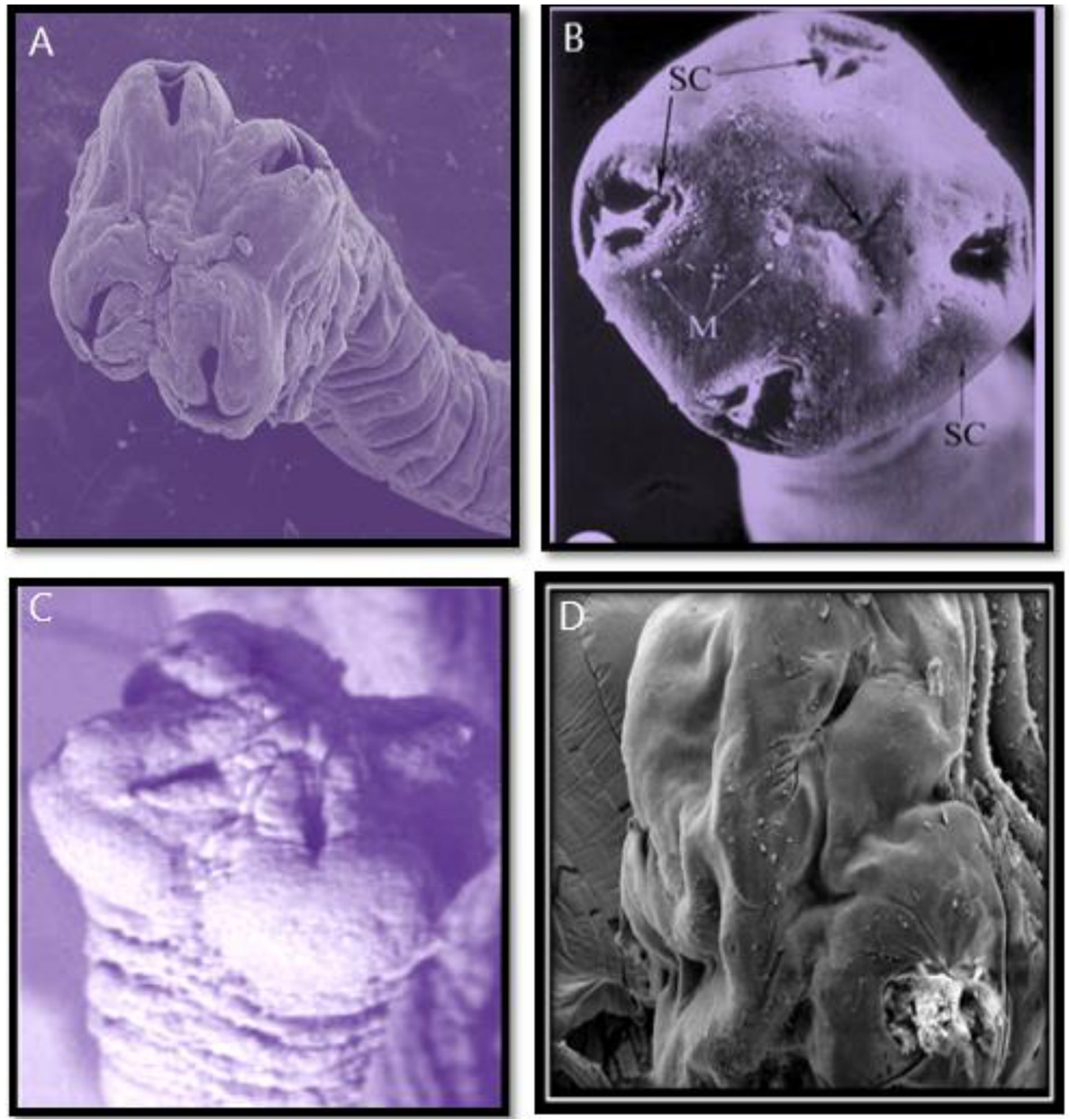

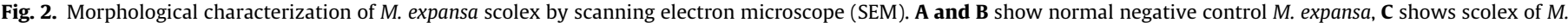
expansa treated with $30 \mu \mathrm{g} / \mathrm{m}$ Spirulina platensis and D refers M. expansa treated with $50 \mu \mathrm{g} / \mathrm{m}$ Spirulina platensis.

subjects Me13, Me13 and Me14, respectively. However, Me Taif2 strain shows about $90 \%$ identity percentage for subject sequence Me22 as shown in Fig. 1.

\subsection{In vitro anthelminthic efficacy of Spirulina platensis extract on Moniezia spp.}

Normal Moniezia expansa shows normal globular scolex with four oval suckers each sucker appears triangular shape, an elongated ribbon-like structure called strobila that consists of several proglottids and unidirectional microtriches covering the whole tegument as in Fig. 2(A, B), 3 (A, B) and 4 (A). However, treatment of Monizia spp. adult tape worms with different concentrations of Spirulina platensis shows deformation especially for higher concentrations 30 and $50 \mu \mathrm{g} / \mathrm{ml}$. It causes the scolex to become more swollen than normal with narrowing of sucker's opening, the proglottids appear deformed with circular areas of pronounced swelling occurred along their margins and microtriches covering the whole tegument appears in several directions Fig. 2 (C, D), 3 (C-E) and 4(B, D).

\section{Discussion}

\subsection{Prevalence and incidence of tape worms in al Taif governorate}

The present study was designed to assess an epidemiological study of cestodes among sheep at Al Taif governorate throughout the whole year from October 2018 to September 2019 in KSA. In the current study the incidence of natural infection with tapeworms was (9.94\%), which is in agreement with many other scientific reports (Khan et al., 1989; Kaur et al., 1995; Umur and Gicik,1995; Mazyad and El-Nemr, 2002), while higher values were reported in this study than those reported by other authors (Tinar et al., 1993; Swarnkar et al., 1996) and lower than that recorded by (Kumar et al., 1989) to $28.5 \%$. These differences may be due to host habits in different countries, parasites, vectors and many environmental factors.

It was found that the highest percent of positively was recorded in October (20\%), while the lowest percent was in September (5\%). According to seasons, it was found that the incidence of tapeworms among sheep was high in winter (11.3), while it is least in spring season (7.72) as shown in Table 1. The results of seasonal incidence of tape worms among sheep recorded in this study were nearly the same all over the year, except for spring. This could be attributed to the climatic conditions including temperature, relative humidity and rainy weather which were favorable to the survival and development of larval stages which were strongly supported by (Qamar, 2009), and the intermediate hosts (oribatid mites) on pasture in $\mathrm{Al}$ Taif governorate (Pomroy, 1997).

The worms that were identified in this study listed in Table 2, Avitellina centripunctata (39.5\%), Moniezia expansa and Moniezia benedeni (36.4\%), Thysaniezia giardia (15.6\%), and Stilesia hepatica (8.3\%). With regard to parasite prevalence throughout the year, the highest values of infection with Moniezia spp. were recorded 

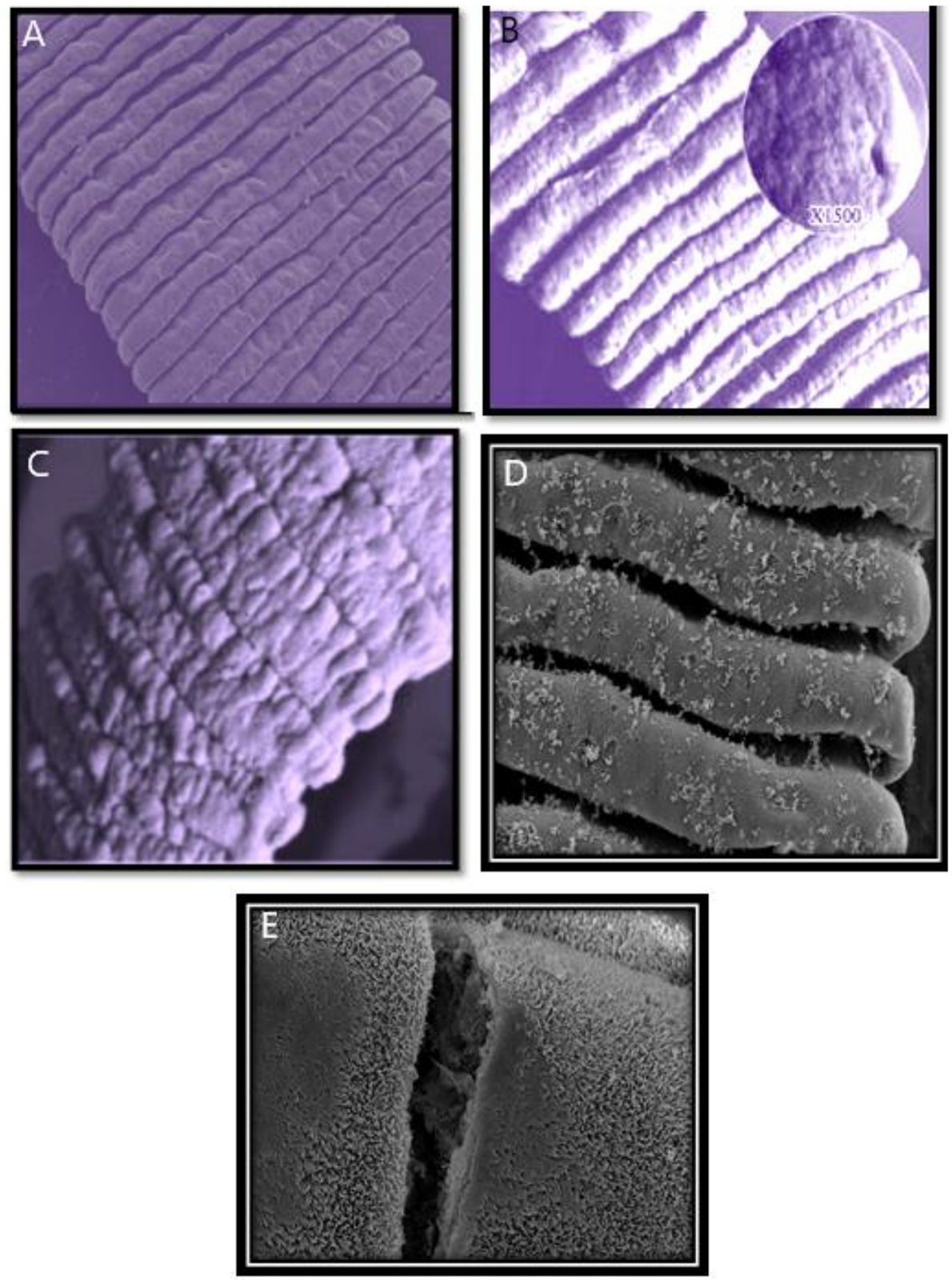

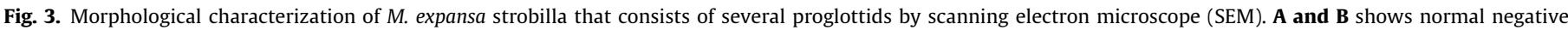
control M. expansa, C shows proglottids of M. expansa treated with $30 \mu \mathrm{g} / \mathrm{m}$ Spirulina platensis and D and E refer to M. expansa treated with $50 \mu \mathrm{g} / \mathrm{m}$ Spirulina platensis.

during the autumn season, and this was consistent with (Pavlasek et al., 1990) and (Sievers et al., 2002).

\subsection{Molecular characterization of Moniezia spp.}

The present results agreed with Diop et al. (2015), they revealed that according to a phylogenetic analysis based on cox1 gene sequences in tapeworms from goats/sheeps and that from cattle were genetically different from each other. The percentage of Al Taif Moniezia species cox1 gene identity were ranged from 90 to $99 \%$; in which Al Taif strains Me Taif1, Me Taif3 and Me Taif4 have identity percentage $99 \%$ in alignment to subjects Me13 (accession number: AB821384.1), Me13 and Me14 (accession number: AB821385.1), respectively but Me Taif 2 shows $90 \%$ identity percentage for subject sequence Me22 (accession number: AB821393.1).

Diop et al. (2015) reported that most Moniezia species cox1 gene (375 bp) of Senegal and Ethiopia including Me13, Me14 and Me22 were already found in Japan tapeworms in the GenBank database with accession number: AB099693 in Genbank (Fukumoto and Onuma, 2003), but there is no host information in the database. They stated that no relevant papers were published and the data was only published in the database. In addition, they compared with the sequences obtained from Moniezia sp. (AB099693) and was equally genetically distant to all the sequences with the similarity of $86.7-87.7 \%$.

The present study revealed the genetic diversity of Al Taif Moniezia sp. might be due to intraspecific variation. This suggestion agreed with (Diop et al., 2015), they suggest that the mitochondrial variability of $M$. expansa in Senegal is due to intraspecific variation rather than interspecific among cryptic species. For anoplocephalid cestodes no reports were found of intraspecific variation of the cox 1 gene sequences between them, but some other types of cyclophyllidean cestodes such as Echinococcus multilocularis and Taenia solium had genetic subgroup in the world with the listed as $1.9 \%$ and $1.3 \%$, respectively (Nakao et al., 2002; 2009). 

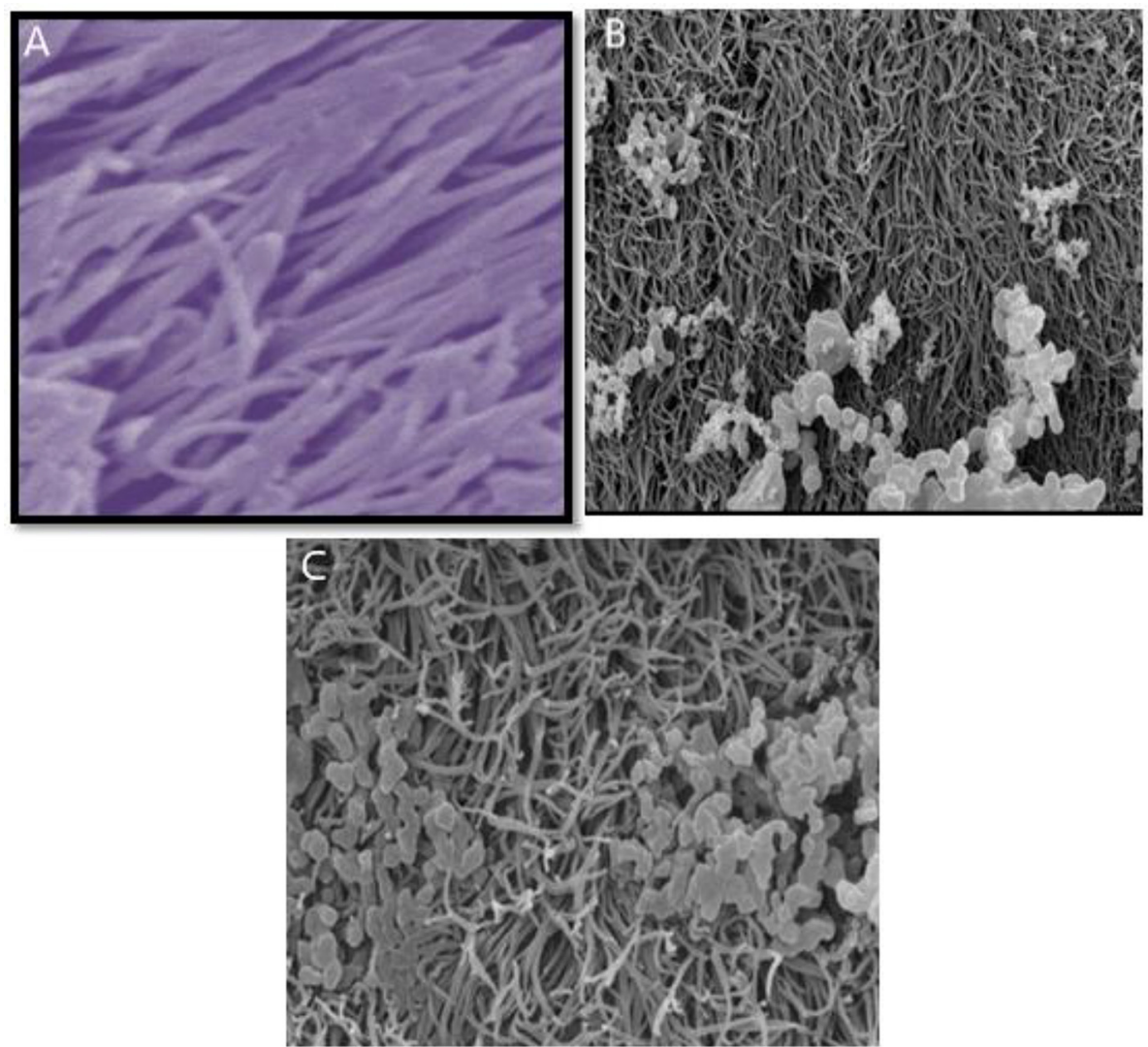

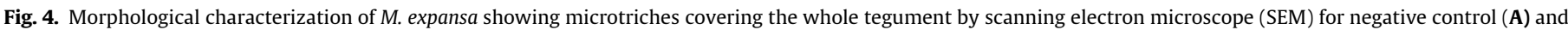
M. expansa treated with $50 \mu \mathrm{g} / \mathrm{m}$ Spirulina platensis (B and C).

4.3. In vitro anthelminthic efficacy of Spirulina platensis extract on Monizia spp.

As per to our knowledge, it is the first time to assess the anthelminthic potential of Spirulina platensis extract on Monizia spp. that was reported by deformation of the tape worm morphology that was treated with Spirulina platensis extract at different concentrations by scanning electron microscopic examination.

The outer surface or tegument is the area of contact between the environment in the host and Monizia, so the tegument has many functions and features, which have made the study of great importance, because the outer surface of the tape worm is the main target site for different natural anthelmintic products and synthetic drugs as proved by ultrastructural and histomorphological studies (Elbanna and Hegazi, 2011; Marcano et al., 2004). These changes depend on the concentration of the extract and the incubation period, leading to deformation and destruction in the scolex and proglottis as well as in the cuticle tegumental architecture of $M$. expansa. One of the main characteristics of parasite cuticle is metabolically active as well as specialized in the selection and absorption of nutrients and the osmoregulation process. Therefore, the deformities and destructive changes on the parasite surface are responsible for the passive diffusion of anthelminthic through the cuticle (Teas et al., 2004; Aly and Abdou, 2010).

Mossa et al. (2000) reported that using different plant extracts of Kingdom of Saudi Arabia have high efficacy in the treatment of Ascariasis and fascioliasis. It had also a bactericidal effect and molluscicidal activity of Schistosoma mansoni and also with less side effects and less expensive than other chemical drugs.
The effect of ethanolic extract of Calligonum comosum and TCBZ on adult worms of Fasciola gigantica was studied by Degheidy et al. (2013) through biochemical and hematological examination. Their results showed a decrease in the number of eggs in the feces and also the blood parameter returned to its normal levels after treatment, which led to the improvement of the health condition of the sheep. In addition, in Al Taif governorate, Kingdom of Saudi Arabia, Degheidy and Al-Otaibi (2017) studied biological control of adult tapeworms (Monizia spp.) by brown algae (Fucus vesiculosus) and their results confirmed the effectiveness of all concentrations, especially $30 \mu \mathrm{g} / \mathrm{ml}$ after one hour.

In the light of our present findings, we conclude that the Spirulina platensis could be a good anthelmintic for moniziasis in sheep. To validate our findings and improve our knowledge on its potential as an anthelmintic drug used for tape worms or in combination of other chemical drug to improve its therapeutic effect more studies are needed.

\section{Declaration of Competing Interest}

The authors declare that they have no known competing financial interests or personal relationships that could have appeared to influence the work reported in this paper.

\section{Acknowledgments}

This work was supported by Taif University Researchers Supporting Project number (TURSP-2020/299), Taif University, Taif, Saudi Arabia. 


\section{References}

Al-Qureishy, S.A., 2008. Prevalence of cestode parasites in sheep slaughtered in Riyadh city, Saudi Arabia. J. Egypt. Soc. Parasitol. 38 (1), 273-280.

Aly, M.S., Abdou, W.L., 2010. The effect of native Spirulina platensis on the developmental biology of Spodoptera littoralis Boisd. J. Genetic Engin. Biotechnol. 8 (1), 65-70

Costa, J.A.V., Freitas, B.C.B., Rosa, G.M., Moraes, L., Morais, M.G., Mitchell, B.G., 2019. Operational and economic aspects of Spirulina-based biorefinery. Bioresour. Technol. 292, 121946.

da Rosa, G.M., Moraes, L., Cardias, B.B., Costa, J.A.V., 2015. Chemical absorption and $\mathrm{CO} 2$ biofixation via the cultivation of Spirulina in semicontinuous mode with nutrient recycle. Bioresour. Technol. 192, 321-327.

Degheidy, N.S., Al-Otaibi, W., 2017. In vitro, the biological control of adult Monizia spp. by brown algae (Fucus vesiculosus) on sheep in Taif Governorate. K.S.A Adv. Environ. Boil. 11 (1), 198-205.

Degheidy, N.S., Sharaf, E.M., Fathi, S.M., 2013. Field evaluation of anthelmentic efficacy of Calligonum comosum against fasciolosis in Sheep at Taif. KSA. Global Veterinaria 11 (4), 377-384.

Dineshbabu, G., Goswami, G., Kumar, R., Sinha, A., Das, D., 2019. Microalgaenutritious, sustainable aqua- and animal feed source. J. Funct. Foods 62, 103545.

Diop, G., Yanagida, T., Hailemariam, Z., Menkir, S., Nakao, M., Sako, Y., Ba, C.T., Ito, A., 2015. Genetic characterization of Moniezia species in Senegal and Ethiopia. Parasitol. Int 64 (5), 256-260.

Echeverria, J., Mestorino, N., Errecalde, J., 2002. Comparative pharmacokinetics of ivermectin after its subcutaneous administration in healthy sheep and sheep infected with mange. J. Vet. Pharma. Therapeut. 25, 159-160.

Elbanna, S.M., Hegazi, M.M., 2011. Screening of some seaweeds species from South Sinai, Red Sea as potential bioinsecticides against mosquito larvae; Culex pipiens. Egypt. Acad. J. biolog. Sci. 2, 21-30.

El-Dakhly, Kh.M., Abo El-Hadid, Sh.M., El-Askalany, M.A., Yanai, T., 2012. An abattoir-based study on helminths of slaughtered sheep in Beni-Suef, Egypt. Beni-Suef Uni. J. Appl. Sci. 1 (1), 49-60.

Fukumoto, S., Onuma, M., 2003. The partial sequence of cytochrome oxidase subunit 1(COX-1) in Anoplocephalidae. Database.

Haukisalmia, V., Laaksonen, S., Oksanen, A., Beckmen, K., Halajian, A., Yanagida, T., Nakao, M., 2018. Molecular taxonomy and subgeneric classification of tapeworms of the genus Moniezia Blanchard, 1891 (Cestoda, Anoplocephalidae) in northern cervids (Alces and Rangifer) Parasit. Int. 67, 218-224.

Ibarra, O.F., Jenkins, D.C., 1984. An in vitro screen for new fasciolicidal agents. Zeitschrift parasitenkunde 70, 655-661.

Kaur, A., Bali, H.S., Dugga, C.L., 1995. Seasonal variation of anoplocephaline cestodes infection in sheep of Punjab. Ind. T. Anim. Sci. 65, 38-40.

Khan, M.N., Hayat, C.S., Chaudhry, A.H., Iqbal, Z., Hayat, B., 1989. Prevalence of gastrointestinal helminths in sheep and goats at Faisalabad abattoir. Paskistan Vet. J. 9, 159-161.

Kumar, D., Jatkar, P.R., Raisinghani, P.M., Kayum, A., Jairath, L.K., Gahlot, G.C., 1989. Prevalence of sub-clinical gastrointestinal parasitism in sheep in Bikaner (Rajasthan). J. Vet. parasitol. 3, 139-142n.

Lafarga, T., 2019. Effect of microalgal biomass incorporation into foods: Nutritional and sensorial attributes of the end products. Algal Res. 41, 101566.

Lone, B.A., Chishti, M.Z., Ahmad, F., Hidayatullah, T., 2012. A survey of gastrointestinal helminth parasites of slaughtered sheep and goats in Ganderbal. Kashmir. Global Veterinaria 8 (4), 338-341.

Marcano, L., Carruyo, I., Del Campo, A., Montiel, X., 2004. Cytotoxicity and mode of action of maleic hydrazide in root tips of Allium cepa L. Environ. Res. 94, 221226.

Mazyad, S.A., El-Nemr, H.I., 2002. The endoparasites of sheep and goats and shepherd in North Sinai Governorate. Egypt. J. Egypt. Soc. Parasitol. 32 (1), 119126.

Mehmood, K., Ijaz, M., Durrani, A.Z., Khan, M.A., Sabir, A.J., Saleem, M.H., 2013. Infection rate and therapeutic trials on various gastrointestinal parasites in sheep and goats in and around Lahore, Pakistan. Pakistan J. Zool. 45 (2), 489494.

Mellau, L.B.S., Nonga, H.E., Karimuribo, E.D., 2010. A slaughterhouse survey of liver lesion in slaughtered cattle, sheep and goats at Arusha. Tanzania. Res. J. Vet. Sci. 3 (3), 179-188.

Morsi, M.M., Hammad, D.M., Rashwan, R., 2016. Efficiency of three bio-components against broad bean beetle (bruchidius incarnates) and their effect on germination, seedling growth and cytogenetic changes of vicia faba L. plants. Res. J. Pharmaceut. Biol. Chem. Sci. 7 (1), 1833-1847.

Mossa, M.A; AI-Yahya, I.A and AI-Meshal (2000): Medicinal plants of Saudi Arabia, 2, King Fahad national library Publication, Riyadh, 001-355.

Nakao, M., Okamoto, M., Sako, Y., Yamasaki, H., Nakaya, K., Ito, A.A., 2002. phylogenetic hypothesis for the distribution of two genotypes of the pig tape worm Taenia solium worldwide. Parasitology 124, 657-662.

Nakao, M., Xiao, N., Okamoto, M., Yanagida, T., Sako, Y., Ito, A., 2009. Geographic pattern of genetic variation in the fox tapeworm Echinococcus multilocularis. Parasitol. Int. 58, 384-389.

Pavlasek, I., Holasova, E., Jelenova, I., 1990. Dynamics of occurrence of endoparasites in lambs. Veterinarstvi 40, 540-543.

Pomroy, W.E. (1997): Cestode parasites of ruminants in New Zealand. In: sustainable control of internal parasites in ruminants. Ed. G.K. Barrell. Animal Industries Workshop: Chapter 18: 225-235.

Prakash, V., Bano, S., Singh, S.P., Yadav, M.P.S., 2010. Prevalence and chemotherapy of monieziosis in goats. Asian J. Animal Sci. 5 (1), 57-59.

Qamar, S.A., 2009. Human health problems and zoonotic diseases. Natual history museum university of Oslo, p. 59.

Renuka, N., Guldhe, A., Prasanna, R., Singh, P., Bux, F., 2018. Microalgae as multifunctional options in modern agriculture: Current trends, prospects and challenges. Biotechnol. Adv. 36, 1255-1273.

Sambrook, J., Fritsch, E.F., Maniatis, T., 1989. Molecular cloning: A laboratory manual. Cold spring harbor laboratory press, New York.

Shalaby, I.M.I., Amer, S.A.M., 2012. Preliminary molecular identification of two helminthes (Moniezia sp. and Paramphistomum sp.) in the Province of Taif Saudi Arabia. World Appl. Sci. J. 17 (8), 986-991.

Sievers, G., Jana, M., Cardenas, C., Nunez, J., 2002. Annual study of the egg and oocyst outputs of gastrointestinal parasites and lungworm larvae in a sheep station of Magallanes, Chile. Arch. Med. Vet. 34 (1), 37-47.

Soulsby, E.J.L. (1986): Helminths, arthropods and protozoa of domistecated animals.7th ed ., EIBS.London.809.

Spolaore, P., Joannis-Cassan, C., Duran, E., Isambert, A., 2006. Commercial applications of microalgae. J. Biosci. Bioeng. 101, 87-96.

Swarnkar, C.P., Singh, D., Srivastava, C.P., Bhagwan, P.S.K., Dimri, U., 1996. A retrospective study on ovine gastrointestinal helminthoses under semi-arid conditions. J. Vet. Parasitol. 10, 15-21.

Teas, J., Pino, S., Critchley, A., Braverman, L.E., 2004. Variability of iodine content in common commercially available edible seaweeds. Thyroid 10, 836-841.

Tinar, R., Coskun, S.Z., Demir, S., Akyol, C.V., Dogan, H., Aydin, L., 1993. Cestode species (Anoplocephalidae) and their prevalence in ruminants slaughtered at the bursa meat and fish plant. veteriner fakultesi dergUludag Unioversitesi, pp. 32-40.

Umur, S., Gicik, Y., 1995. Incidence of Anoplocephalidae species in ruminants in kars district. Turk Parazitoloii Dergist 19, 272-281.

Yanagida and Nakao, 2013a. Moniezia expansa mitochondrial cox1 gene for cytochrome c oxidase subunit 1, partial cds, haplotype: Me13. GenBank: AB821384.1.

Yanagida and Nakao, 2013b. Moniezia expansa mitochondrial cox1 gene for cytochrome c oxidase subunit 1, partial cds, haplotype: Me14. GenBank: AB821385.1.

Yanagida and Nakao, 2013c. Moniezia expansa mitochondrial cox1 gene for cytochrome c oxidase subunit 1, partial cds, haplotype: Me22. GenBank: AB821393.1.

Waller, P.J., 2006. Sustainable nematode parasite control strategies for ruminant livestock by grazing management and biological control. Animal Feed Sci. Technol. 126 (3), 277-289. 